Економічні науки: збірник наукових праиь Луиького національного технічного університету. - Серія "Регіональна економіка". - Випуск 15 (59). - Редкол.: відп. ред. д.е.н., професор Л.Л. Ковальська. - Луцьк: ІВВ Луиького НТУ, 2018. - 292 с.

УДК 330.4:338.2; 351

Вороненко I.В., к.е.н., старший науковий співробітник Національний університет біоресурсів і природокористування України

\title{
МОНІТОРИНГ КЛЮЧОВИХ ІНДИКАТОРІВ НАЦІОНАЛЬНОЇ БЕЗПЕКИ ЯК СКЛАДОВА РОЗВИТКУ ЕКОНОМІКИ В УМОВАХ ЦИФРОВІЗАЦІЇ
}

У статті здійснено функціональний та кореляційний аналіз індикаторів моніторингу національної безпеки як складової процесу побудови єдиного інтегрального показника, який буде включати усі аспекти функціонування ринку інформаційно-комунікаційних технологій, та, як наслідок, надавати більш цілісну його характеристику.

Ключові слова: індекси; безпека; кібербезпека; інформаційнокомунікаційні технології; цифровізація. 


\section{Voronenko I.}

\section{MONITORING OF THE NATIONAL SECURITY KEY INDICATORS AS A PART OF ECONOMIC DEVELOPMENT IN THE CONDITIONS OF DIGITIZATION}

Abstract. The article states that the unprecedented development of information and communication technologies and mass media has a big impact on all spheres of economic activity and general security state for every country and not only of a particular one. The functional and correlation analysis of national security monitoring indicators was conducted in which national security was presented as a component of economic development in the conditions of digitalization. To the list of analyzed indexes we can include Global Peace Index, Rule of Law Index, Global Cybersecurity Index and National Cybersecurity Index. The structure of the indicators which were included to the indexes calculation, as well as the mechanism of integral index calculation was established. The existence of the quite high level of correlation at the high level of significance between the Rule of Law Index and the Global Peace Index was found. The available data on the dynamics of the studied indexes by countries during recent years have been presented. The tendency towards certain stagnation of the Global Peace Index and Rule of Law Index for different regions of the world and the general improvement of the Global Cybersecurity Index was indicated. The conducted functional and correlation analysis of the national security monitoring indicators is a part of the building process of a single integral indicator, which will include all aspects of the information and communication technology market functioning, and consequently, will provide a more complete description of it.

Key words: indices; security; cybersecurity; information and communication technologies; digitalization

Вороненко И.В.

\section{МОНИТОРИНГ КЛЮЧЕВЫХ ИНДИКАТОРОВ НАЦИОНАЛЬНОЙ БЕЗОПАСНОСТИ КАК СОСТАВЛЯЮЩАЯ РАЗВИТИЯ ЭКОНОМИКИ В УСЛОВИЯХ ЦИФРОВИЗАЦИИ}

В статье проведённый функциональный и корреляционной анализ индикаторов мониторинга национальной безопасности как составляющей процесса построение единого интегрального показателя, который будет включать все аспекты функционирование рынка информационнокоммуникационных технологий, и, как следствие, предоставлять более целостную его характеристику.

Ключевые слова: индексы; безопасность; кибербезопасность; информационно-коммуникационные технологии; цифровизация. 
Економічні науки: збірник наукових праџь Луцького національного технічного університету. - Серія "Регіональна економіка". - Випуск 15 (59). - Редкол.: відп. ред. д.е.н., професор Л.Л. Ковальська. - Луиьк: ІВВ Луиьького НТУ, 2018. - 292 с.

\section{Постановка проблеми у загальному вигляді та іï} зв'язок 3 важливими науковими та практичними завданнями. Початок XXI століття характеризується безпрецедентним розвитком інформаційно-комунікаційних технологій та засобів масової інформації, а також зростанням у геометричній прогресії ступеня їх впливу на всі сфери економічної діяльності не лише конкретної країни, а й світу в цілому, більш того, на його загальну безпеку. Підкреслимо, що у Законі України «Про основи національної безпеки України» зазначено, що «Державна політика у сферах національної безпеки і оборони спрямована на захист: людини і громадянина - їхніх життя i гідності, конституційних прав i свобод, безпечних умов життєдіяльності; суспільства - його демократичних цінностей, добробуту та умов для сталого розвитку; держави - iї конституційного ладу, суверенітету, територіальної цілісності та недоторканності; території, навколишнього природного середовища - від надзвичайних ситуацій. Державна політика у сферах національної безпеки і оборони спрямовується на забезпечення воєнної, зовнішньополітичної, державної, економічної, інформаційної, екологічної безпеки, кібербезпеки України тощо» [1]. Водночас у затвердженій Указом Президента України «Доктрині інформаційної безпеки України» зазначається «Комплексний характер актуальних загроз національній безпеці в інформаційній сфері потребує визначення інноваційних підходів до формування системи захисту та розвитку інформаційного простору в умовах глобалізації та вільного обігу інформації. Пріоритетами державної політики в інформаційній сфері мають бути: забезпечення інформаційної безпеки; забезпечення захисту і розвитку інформаційного простору України, а також конституційного права громадян на інформацію; відкритість та прозорість держави перед громадянами; формування позитивного міжнародного іміджу України» [2].

У цих умовах, погоджуючись також з С.О. Довгим, що «достовірні та точні статистичні дані є ключовим чинником для розуміння економічних і соціальних явищ» [3], вважаємо за 
Економічні науки: збірник наукових праиь Луиького національного технічного університету. - Серія "Регіональна економіка". - Випуск 15 (59). - Редкол.: відп. ред. д.е.н., професор Л.Л. Ковальська. - Луцьк: ІВВ Луиького НТУ, 2018. - 292 с.

доцільне звернутися до аналізу систем індикаторів вимірювання ключових індикаторів національної безпеки як складової розвитку економіки в умовах цифровізації.

Аналіз останніх досліджень, у яких започатковано вирішення проблеми. Дослідженню різних систем індикаторів розвитку світового ринку ІКТ приділяється багато уваги різними вітчизняними та зарубіжними вченими, зокрема О. Довгим [3], Г. Коломійцем [4], Б. Сану [5], М. Фархаді [6]. Проблематиці моніторингу загроз безпеки України присвячено роботи багатьох вчених, серед яких: С. Бєлай [7], О. Гарущак [8], Є. Кобко [9], С. Польовик [10]. Безпосередньо 3 самою статистичною інформацією щодо конкретної системи індикаторів, а також іiі функціональним аналізом можна ознайомитися на офіційних сайтах міжнародних організацій та агентств.

Варто зазначити, що на сьогодні відсутні системні наукові праці, в яких здійснено функціональний та кореляційний аналіз індикаторів моніторингу розвитку національної безпеки.

Попередній аналіз структури існуючих індикаторів у цій сфері, на наш погляд, дозволяє зробити висновок щодо доцільності дослідження у зазначеному контексті індексу світового спокою (Global Peace Index), субіндексом якого в тому числі $\epsilon$ «військові витрати у відсотках від ВВП), а також індексу верховенства права (Rule of Law Index).

Крім цього враховуючи, що відповідно до 7 принципу цифровізації, наведеного у Концепції розвитку цифрової економіки та суспільства України на 2018-2020 роки «цифровізація повинна супроводжуватися підвищенням рівня довіри і безпеки, тобто інформаційна безпека, кібербезпека, захист персональних даних, недоторканність особистого життя та прав користувачів цифрових технологій, зміцнення та захист довіри у кіберпросторі $\epsilon$, зокрема, передумовами одночасного цифрового розвитку та відповідного попередження, усунення та управління супутніми ризиками» [11] для моніторингу національної безпеки як складової розвитку економіки в умовах цифровізації, на наш погляд, також доцільно дослідити 

університету. - Серія "Регіональна економіка". - Випуск 15 (59). - Редкол.: відп. ред. д.е.н., професор Л.Л. Ковальська. - Луиьк: ІВВ Луиького НТУ, 2018. - 292 с.

глобальний індекс кібербезпеки (Global Cybersecurity Index), a також аналогічний індекс, а саме національної кібербезпеки (National Cybersecurity Index) запропонований NCSI Project Team. Відтак, вважаємо за доцільне здійснити функціональний, статистичний та кореляційний аналіз вищеназваних індексів.

Цілі cmammi. Метою статті $\epsilon$ функціональний та кореляційний аналіз індикаторів моніторингу національної безпеки як складової розвитку економіки в умовах цифровізації, а саме індексів: світового спокою, верховенства права, глобальної кібербезпеки та національної кібербезпеки.

Виклад основного матеріалу дослідження 3 обгрунтуванням отриманих наукових результатів. Індекс світового спокою - це поточний проект, що реалізується Economist Intelligence Unit, в межах якого оцінюються показники, що охоплюють три області, які підходять для оцінки реальних або потенційних загроз спокою, вимірюється відносна миролюбність націй [12]. Для наочності на рис. 1 наведено структуру показників, що включаються при розрахунку індексу світового спокою.

Зазначимо, що кожному показнику надається оцінка від 1 до 5, причому 1 характеризує найбільший спокій, а 5 найменший [13]. Наприкінці розрахунків загальний бал для кожної країни зважується відповідно до "внутрішніх" та “зовнішніх" факторів спокою, щоб досягнути загального рейтингу відносної миролюбності. Після чого формується інтегральний показник, застосовуючи вагу у 60 відсотків до складових внутрішнього спокою і 40 відсотків для зовнішнього. 
Економічні науки: збірник наукових праџь Луцького національного технічного університету. - Серія "Регіональна економіка". - Випуск 15 (59). - Редкол.: відп. ред. д.е.н., професор Л.Л. Ковальська. - Луцьк: ІВВ Луцького НТУ, 2018. - 292 с.

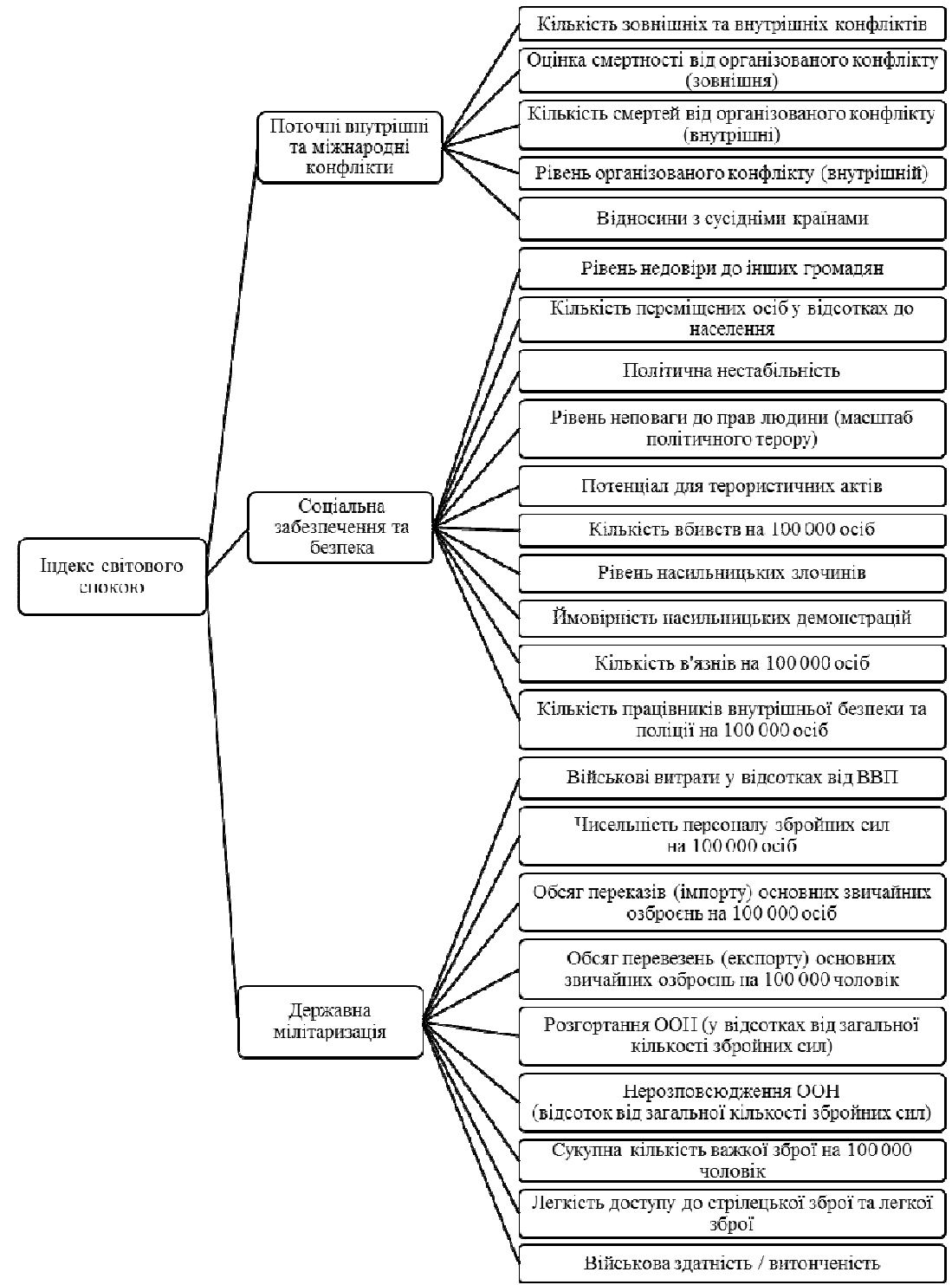

\section{Рис. 1. Структура показників, що включаються при розрахунку індексу світового спокою \\ * розроблено автором за даними $[12,13]$}


Економічні науки: збірник наукових праџь Луцького національного технічного університету. - Серія "Регіональна економіка". - Випуск 15 (59). - Редкол.: відп. ред. д.е.н., професор Л.Л. Ковальська. - Луиьк: ІВВ Луиького НТУ, 2018. - 292 с.

На рис. 2 для наочності наведено аналіз стану індексу світового спокою для 163 країн світу. За даними 2018 року першість за даним рейтингом отримала Ісландія, за нею розташувалася Нова Зеландія, а далі знов країни Європи: Австрія, Португалія, Данія. Останнє місце посіла Сирія [13].

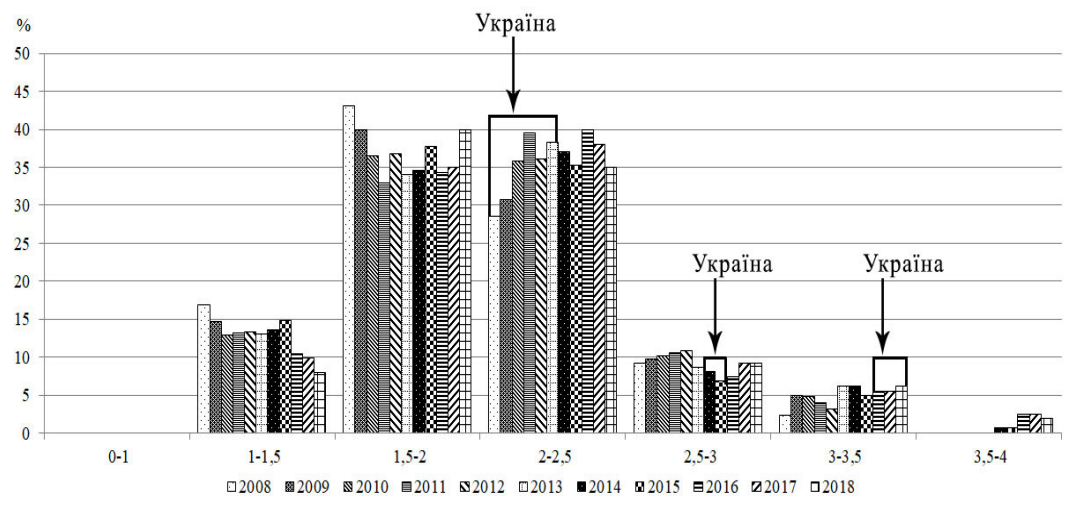

Рис. 2. Динаміка індексу світового спокою за країнами світу *розроблено автором за даними [13, 14]

Підкреслимо наявність тенденції щодо певного погіршення індексу за роками в цілому по світу. Так, якщо за даними 2008 року 17\% досліджуваних країн мали високий індекс світового спокою (значення індексу від 1 до 1,5), то у 2018 році таких країн було 8\% від загальної кількості; індекс від 1,5 до 2,0 у 2008 році був у 43\%, в 2018 році у 43\%. Водночас зазначимо, що за досліджуваний період жодній країні світу не надано найвищий рівень за індексом світового спокою (значення індексу від 0 до 1). Щодо України, то в 2008 році індекс світового спокою складав 2,02, у 2016 році погіршився до 3,287, в 2018 році дещо поліпшився до 3,113. Зазначимо, що незважаючи на певне поліпшення даного індексу за останні роки за даними 2018 року Україна займає 152 місце зі 163 досліджуваних країн [13]. 
Економічні науки: збірник наукових праџь Луцького національного технічного університету. - Серія "Регіональна економіка". - Випуск 15 (59). - Редкол.: відп. ред. д.е.н., професор Л.Л. Ковальська. - Луцьк: ІВВ Луцького НТУ, 2018. - 292 с.

«Індекс верховенства права в світовому праві»є проектом World Justice Project, що спирається на понад 110000 домашніх та експертних досліджень, які здійснюються за участю консультацій з науковцями, практиками та лідерами громад зі всього світу, щоб виміряти як верховенство права відчувається і сприймається в повсякденному житті в усьому світі та визначає як верховенство закону відчувається та сприймається широкою громадськістю по всьому світу [15]. Для наочності на рис. 3 наведено структуру факторів та показників, що включаються при розрахунку індексу верховенства права. Зазначимо, “неформальне правосуддя" (фактор 9) не порівнюються між країнами і тому не входять до показників та рейтингу даного індексу.

Розрахунок індексу здійснюється виходячи з п'яти анкет, що базуються на концептуальній структурі даного індексу та призначаються експертам та широкій громадськості, які заповнюються визначеними в кожній країні понад 300 потенційними місцевими експертами, а також залученими службами провідних місцевих виборчих дільниць для проведення домашніх опитувань [15]. Остаточна оцінка здійснюється на основі наступного п'ятиетапного процесу: кодифікація позицій анкети у вигляді числових значень, розрахунок “сірих" балів країни шляхом об'єднання відповідей експертів або громадськості; нормалізація вихідних балів; зведення нормалізованих оцінок до субфакторів та факторів, що використовують прості середні значення; формування остаточних рейтингів за допомогою нормалізованих балів. Зазначимо, для виявлення можливих упереджень та помилок команда експертів перевіряє всі субфактори понад ніж 60 сторонніми джерелами, включаючи кількісні дані та якісні оцінки, отримані від місцевих та міжнародних організацій, аналіз чутливості проводиться за участю Спільного дослідницького центру Свропейської комісії. 
Економічні науки: збірник наукових праџь Луцького національного технічного університету. - Серія "Регіональна економіка". - Випуск 15 (59). - Редкол.: відп. ред. д.е.н., професор Л.Л. Ковальська. - Луиьк: ІВВ Луияького НТУ, 2018. - 292 с.

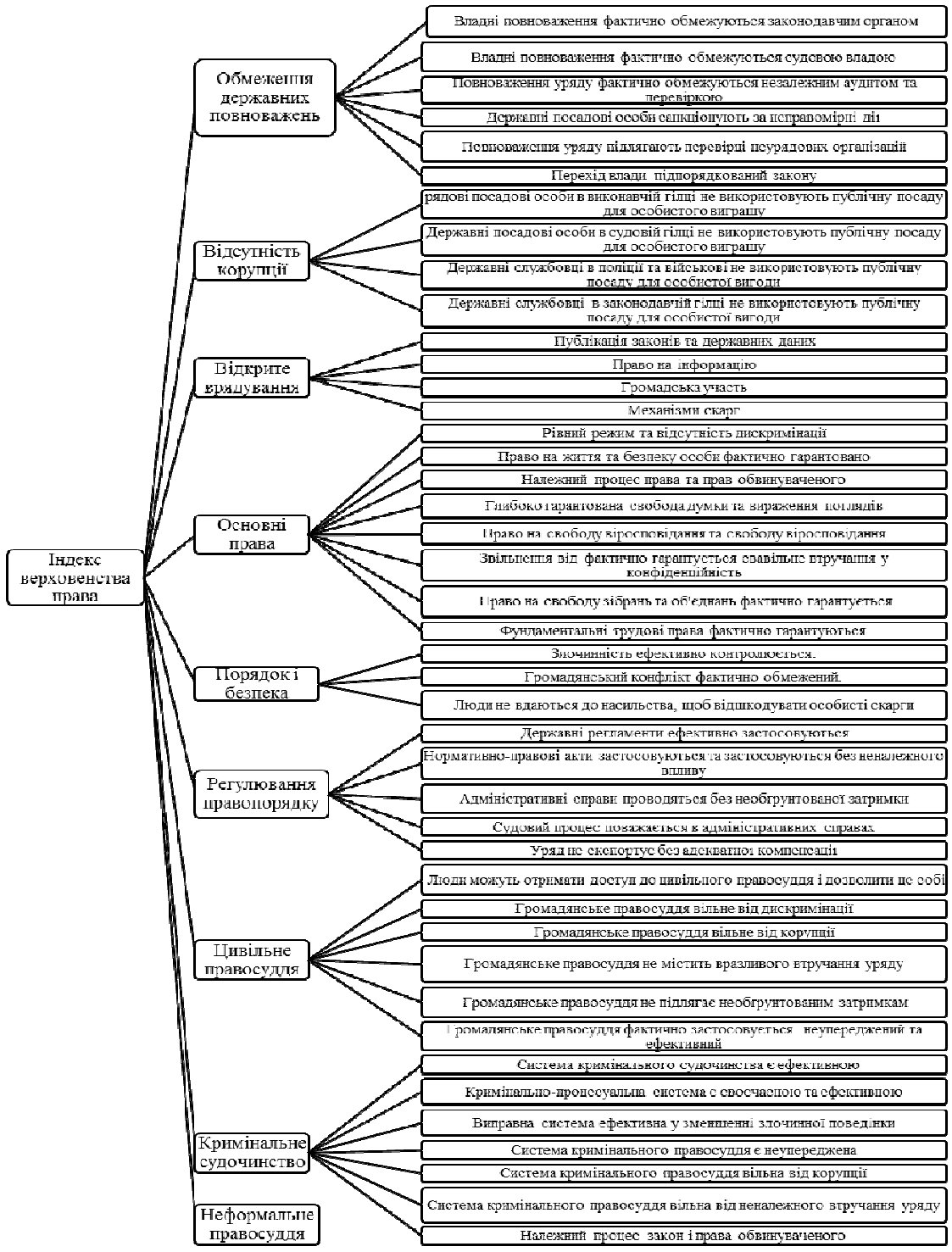

\section{Рис. 3. Структура показників, що включаються при розрахунку індексу верховенства права}


Економічні науки: збірник наукових праиь Луиького національного технічного університету. - Серія "Регіональна економіка". - Випуск 15 (59). - Редкол.: відп. ред. д.е.н., професор Л.Л. Ковальська. - Луиьк: ІВВ Луиького НТУ, 2018. - 292 с.

На рис. 4 для наочності наведено аналіз стану індексу верховенства права у світі для 98 країн світу. За даними 20172018 років першість за індексом верховенства права отримали наступні країни Свропи: Данія, Норвегія, Фінляндія, Швеція, Нідерланди, Німеччина, за ними розташувалася Нова Зеландія. Останнє місце посіли Венесуела та Камбоджа [16].

*розроблено автором за даними [15]

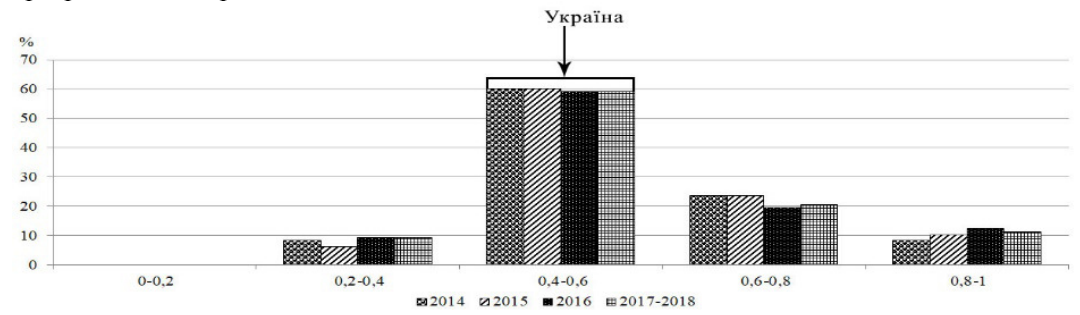

Рис. 4. Динаміка індексу верховенства права у світі *розроблено автором за даними [16]

Зазначимо наявність тенденції стагнації даного індексу за досліджуваний період в цілому по світу. Так, якщо за даними 2014 року 8\% досліджуваних країн мали високий індекс верховенства права (значення індексу від 0,2 до 0,4), то у 2017-2018 роках таких країн було 9\% від загальної кількості; індекс від 0,4 до 0,6 у 2014 році був у 60\%, в 2017-2018 роках у $59 \%$. Водночас зазначимо, що за досліджуваний період жодній країні світу, аналогічно до індексу світового спокою, не надано найвищий рівень за індексом верховенства права (значення індексу від 0 до 0,2). Щодо України, то в 2014 році індекс верховенства права складав 0,47 , в 2018 році склав 0,5 .

Глобальний індекс кібербезпеки, представлений громадськості у 2014 році та суттєво змінений у звітах за 2015 та 2017 роки Міжнародним союзом електрозв'язку, який $\epsilon$ спеціалізованою установою ООН з ІКТ [17], є багатосторонньою ініціативою, метою якої $\epsilon$ визначення готовності країн до кібербезпеки за наступними 5 напрямами: юридичний (на основі існування правових установ та рамок, що стосуються кібербезпеки та кіберзлочинів); технічний (на базі наявності 
Економічні науки: збірник наукових праџь Луцького національного технічного університету. - Серія "Регіональна економіка". - Випуск 15 (59). - Редкол.: відп. ред. д.е.н., професор Л.Л. Ковальська. - Луцьк: ІВВ Луиького НТУ, 2018. - 292 с.

технічних інститутів та структур, що стосуються кібербезпеки); організаційний (на основі наявності інституцій координації політики та стратегій розвитку кібербезпеки на національному рівні); розвиток потенціалу (на основі існуючих програм досліджень та розробок, освітніх та навчальних програм, сертифікованих фахівців та установ державного сектору, що сприяють створенню потенціалу); співпраця (на основі існування партнерських відносин, кооперативних рамок та мереж обміну інформацією) [18]. Для наочності на рис. 5 наведено структуру показників, що включаються при розрахунку глобального індексу кібербезпепеки.

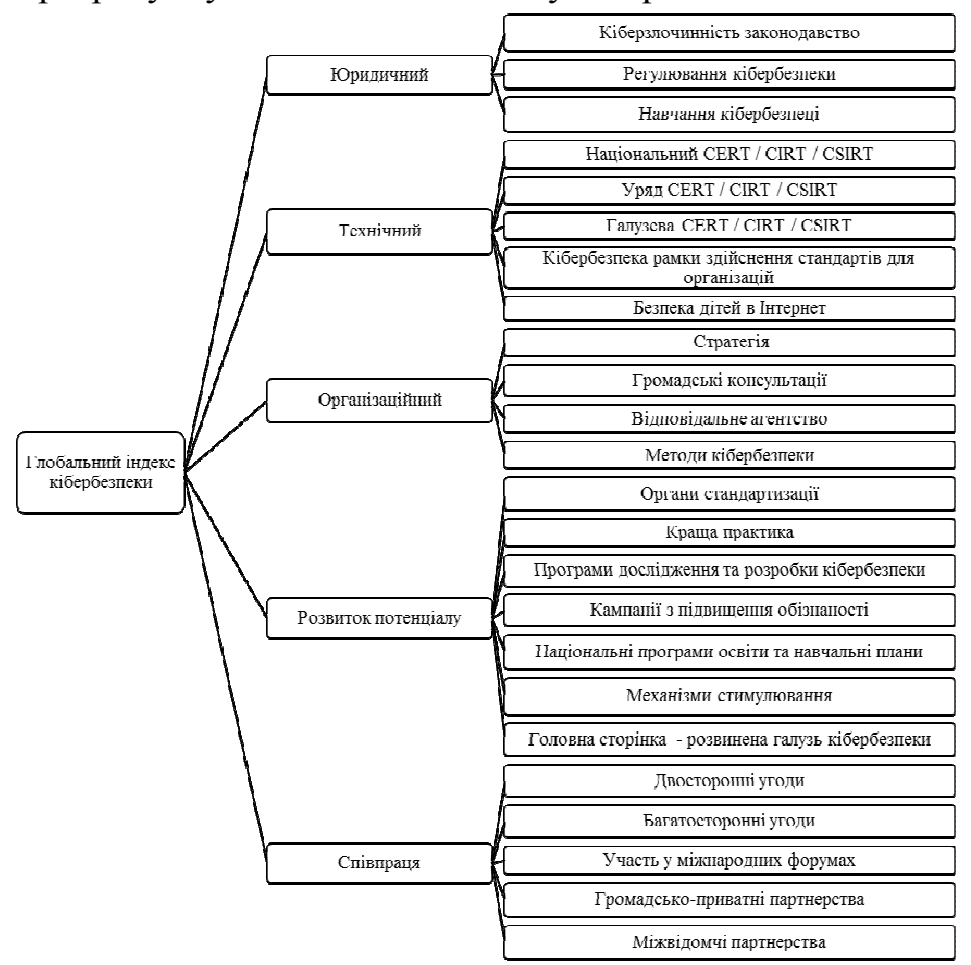

Рис. 5. Структура показників, що включаються при розрахунку глобального індексу кібербезпепеки (розроблено автором за даними [18]) 
Економічні науки: збірник наукових праџь Луцького національного технічного університету. - Серія "Регіональна економіка". - Випуск 15 (59). - Редкол.: відп. ред. д.е.н., професор Л.Л. Ковальська. - Луцьк: ІВВ Луиького НТУ, 2018. - 292 с.

Глобальний індекс кібербезпеки містить 25 індикаторів та 157 питань, що були відібрані за наступними критеріями: відповідність п'яти ключових елементів глобального індексу кібербезпеки та сприяння досягненню основних цілей та концептуальних рамок Програми глобальної кібербезпеки; наявність та якість даних; можливість перехресної перевірки за допомогою вторинних даних [18]. Розрахунок індикаторів, що використовуються для визначення глобального індексу кібербезпеки базується на карті дерева розробки кібербезпеки та бінарних варіантах відповіді.

На рис. 6 для наочності наведено аналіз стану глобального індексу кібербезпеки для 193 країн світу [19]. За даними 2017 року першість в глобальному індексі кібербезпеки отримав Сінгапур, за ним розташувалися Сполучені Штати Америки, Малайзія та Оман. Серед країн Свропи лідирують Естонія, Франція і Норвегія. Останнє місце посіла Екваторіальна Гвінея.

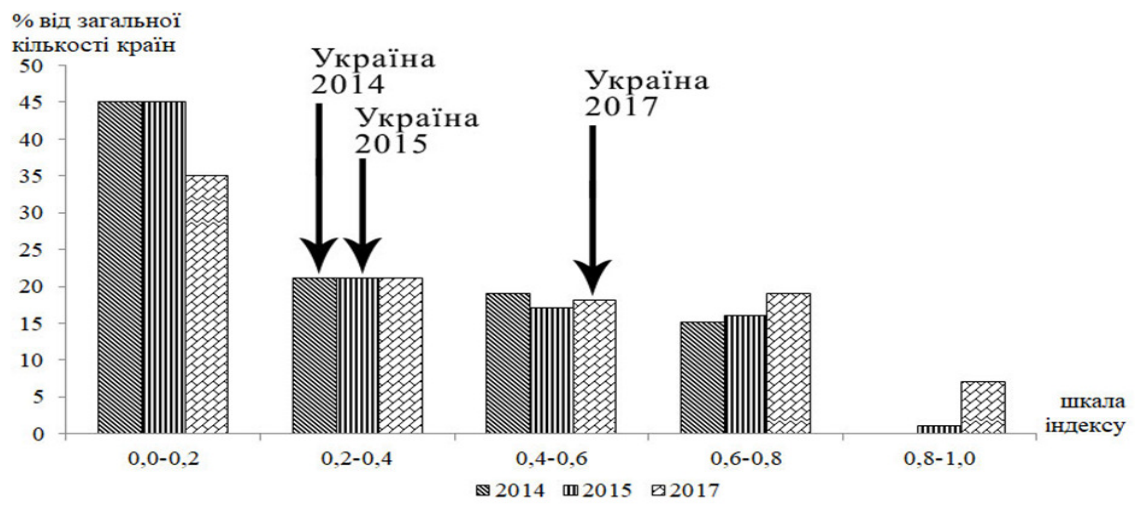

Рис. 6. Динаміка глобального індексу кібербезпеки за країнами світу (розроблено автором за даними [19])

Підкреслимо наявність тенденції щодо покращення індексу за роками в цілому по світу. Так, якщо за даними 2014 року не було жодної країни 3 найвищим глобальним індексом кібербезпеки (значення індексу понад 0,8), то в 
Економічні науки: збірник наукових праиь Луиького національного технічного університету. - Серія "Регіональна економіка". - Випуск 15 (59). - Редкол.: відп. ред. д.е.н., професор Л.Л. Ковальська. - Луцьк: ІВВ Луиького НТУ, 2018. - 292 с.

2017 році таких країн було 7\% від загальної кількості досліджуваних країн; індекс від 0,6 до 0,8 у 2014 році був у $15 \%$, а в 2017 році у $19 \%$. Щодо України, то в 2014 році глобальний індекс кібербезпеки складав 0,35, а в 2017 році - 0,5, відтак, незважаючи на поліпшення за досліджуваний період можна говорити про недостатній рівень кібербезпеки.

Національний індекс кібербезпеки є аналогом глобального індексу кібербезпеки, запропонований NCSI Project Team, та є глобальним індексом, який вимірює готовність країн запобігати кіберзагрозам та управляти кіберінцидентами та, як зазначається його розробниками, $€$ базою даних із загальнодоступними матеріалами для доказів та інструментом для нарощування національних можливостей у сфері кібербезпеки [20]. Індикатори національного індексу кібербезпеки були розроблені відповідно до національної системи кібербезпеки з урахуванням фундаментальних кіберзагроз: відмова від надання електронних послуг - послуги недоступні; порушення цілісності даних несанкціонована модифікація; порушення конфіденційності даних - викрита таємність. Для визначення даного індексу оцінюється ситуація в галузі кібербезпеки в країні шляхом створення глобальної бази даних, яка містить посилання та документи про національний кіберзахист за індикаторами, що наведені на рис. 7.

Розрахунок індексу здійснюється групою експертів шляхом присвоєння 1 бала за наявність правового акту, який регулює конкретну область; 2-4 балів - підрозділ, який має певну відповідальність за кіберзахист; 2 балів - співпрацю у цій сфері; 1-3 бали - результат (документ, вправи, технології тощо) [20]. Інтегральний показник значення індексу для країни розраховується як частка балів, що відповідно до розрахунку отримала дана країна на загальну максимальну кількість балів (100) помножити на 100. 
Економічні науки: збірник наукових праць Луиького національного технічного університету. - Серія "Регіональна економіка". - Випуск 15 (59). - Редкол.: відп. ред. д.е.н., професор Л.Л. Ковальська. - Луиьк: ІВВ Луиького НТУ, 2018. - 292 с.

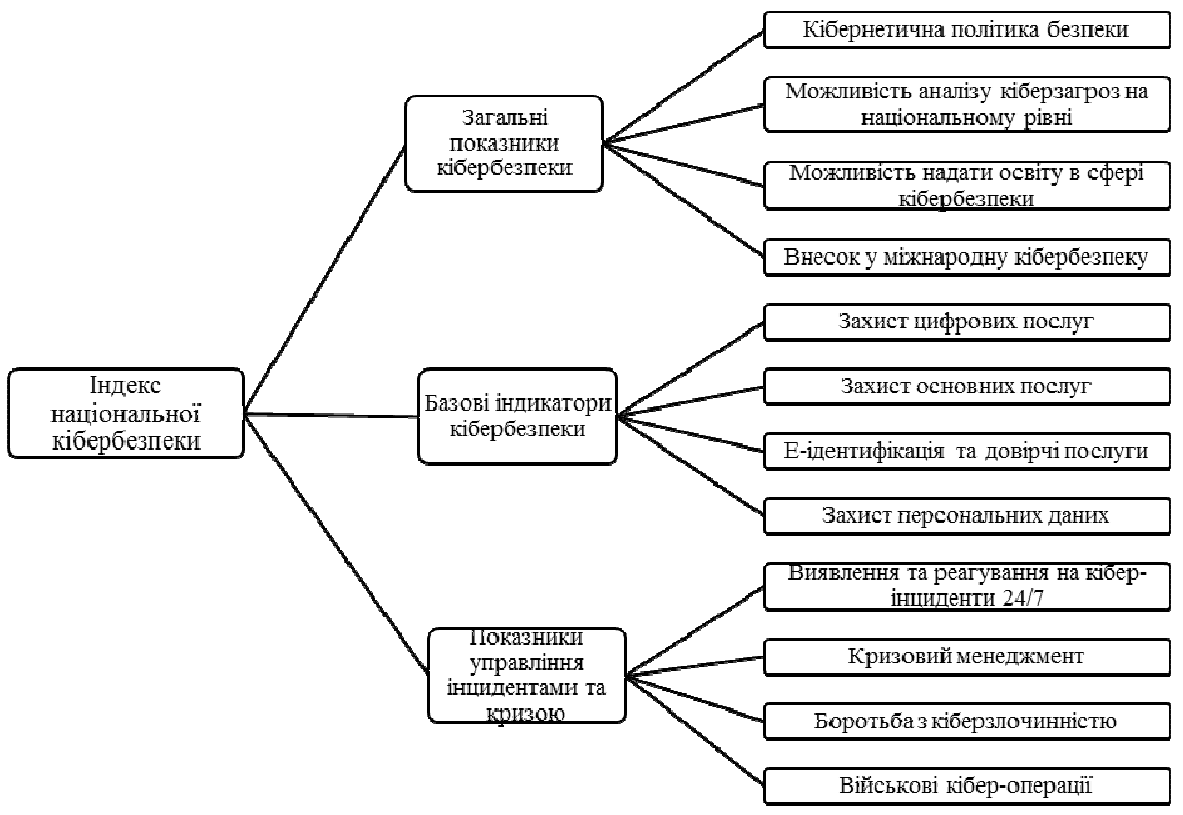

Рис. 7. Структура показників, що включаються при розрахунку національного індексу кібербезпеки *розроблено автором за даними [20]

На рис. 8 для наочності наведено наявні дані щодо національного індексу кібербезпеки для 114 країн світу. За даними 2018 року першість за рівнем національної кібербезпеки отримали наступні країни Європи: Естонія, Франція, Німеччина та Словаччина. Останнє місце поділили Південний Судан та Кірібаті. 
Економічні науки: збірник наукових праць Луцького національного технічного університету. - Серія "Регіональна економіка". - Випуск 15 (59). - Редкол.: відп. ред. д.е.н., професор Л.Л. Ковальська. - Луцьк: ІВВ Луиького НТУ, 2018. - 292 с.

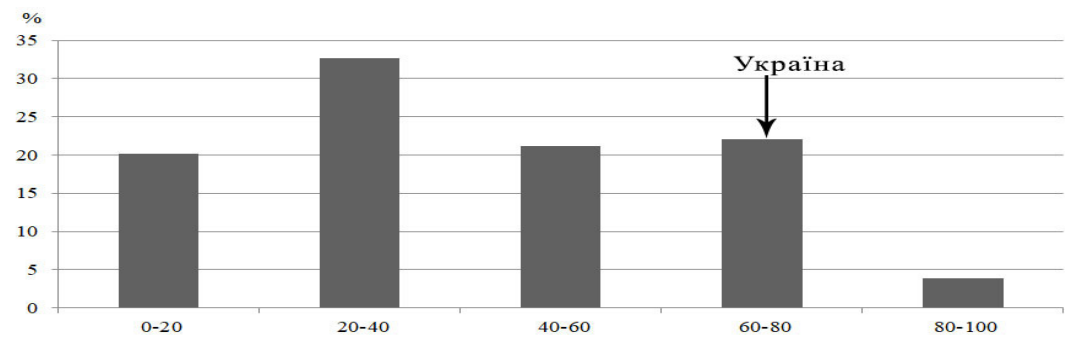

Рис. 8. Дані щодо національного індексу кібербезпеки за країнами світу

*розроблено автором за даними [21]

За даними 2018 року 4 \% досліджуваних країн мають найвищий рівень кібербезпеки, індекс від 60 до 80 у 22\% країн. Щодо України, то значення даного індексу складає 63,64, відтак порівнюючи результати дослідження NCSI Project Team 3 Міжнародним союзом електрозв'язку можна відзначити наявні розбіжності, як за абсолютними та відносними показниками. Так, Міжнародний союз електрозв'язку з максимального 1 бала надав Україні 0,5, Україна зайняла 59 місце серед 165 країн світу. В той час як NCSI Project Tеат надало Україні 63,64 бали 3 максимальних 100, Україна зайняла 23 місце серед 114 країн світу.

Розглядаючи побудовану кореляційну матрицю (табл. 1) між розглянутими індексами, яка була розрахована на основі 36 до 100 спостережень (в залежності від наявних даних) за 2017 рік, можна зробити висновок, що найбільше корелюють між собою індекси верховенства права та світового спокою $(-0,75)$ на високому рівні значимості, що свідчить про наявність спільних факторів та показників в структурі їх субіндексів. Також можна говорити про наявність певної залежності між глобальним індексами глобальної кібербезпеки та верховенства права та глобальним індексом кібербезпеки та національним індексом кібербезпеки. 
Економічні науки: збірник наукових праџь Луцького національного технічного університету. - Серія "Регіональна економіка". - Випуск 15 (59). - Редкол.: відп. ред. д.е.н., професор Л.Л. Ковальська. - Луиьк: ІВВ Луиького НТУ, 2018. - 292 с.

Таблиця 1

Кореляційна матриця за даними 2017 року

\begin{tabular}{|l|c|c|c|c|}
\hline \multicolumn{1}{|c|}{ Назва індексу } & $\begin{array}{c}\text { Індекс } \\
\text { світового } \\
\text { спокою }\end{array}$ & $\begin{array}{c}\text { Індекс } \\
\text { верховенства } \\
\text { права }\end{array}$ & $\begin{array}{c}\text { Глобальний } \\
\text { індекс } \\
\text { кібербезпеки }\end{array}$ & $\begin{array}{c}\text { Національний } \\
\text { індекс } \\
\text { кібербезпеки }\end{array}$ \\
\hline $\begin{array}{l}\text { Індекс світового } \\
\text { спокою }\end{array}$ & 1 & & & \\
\hline $\begin{array}{l}\text { Індекс верховенства } \\
\text { права }\end{array}$ & $\begin{array}{l}-0,75^{* *} / \\
\mathrm{n} * * *=62\end{array}$ & 1 & 1 & \\
\hline $\begin{array}{l}\text { Глобальний індекс } \\
\text { кібербезпеки }\end{array}$ & $-0,31^{* * / n=83}$ & $0,59 * * / \mathrm{n}=70$ & & \\
\hline $\begin{array}{l}\text { Національний індекс } \\
\text { кібербезпеки }\end{array}$ & $-0,48^{* *} / \mathrm{n}=83$ & $0,38 * / \mathrm{n}=36$ & $\begin{array}{c}0,69 * * / \\
\mathrm{n}=100\end{array}$ & 1 \\
\hline
\end{tabular}

Довідково: * $=\mathrm{p}<0,3 ; * *=\mathrm{p}<0,001$

*** - кількість спостережень

*розроблено автором за даними [13; $14 ; 16 ; 19,21]$

Висновки. Отже, державна політика у сферах національної безпеки і оборони спрямовується на забезпечення воєнної, зовнішньополітичної, державної, економічної, інформаційної, екологічної безпеки, кібербезпеки України тощо. Водночас відсутність в Україні методології оцінки національної безпеки наразі унеможливлює можливість здійснити об'єктивну оцінку цих процесів. В роботі наведено результати функціонального та кореляційного аналізу індикаторів моніторингу національної безпеки як складової розвитку економіки в умовах цифровізації, а саме індексів: світового спокою, верховенства права, глобальної кібербезпеки та національної кібербезпеки.

Незважаючи на те, що досліджувані індекси розглядають різні аспекти, наявний взаємозв'язок між індексами верховенства права та світового спокою на високому рівні значимості. Також можна говорити про наявність певної залежності між глобальними індексами глобальної кібербезпеки та верховенства права та глобальним індексом кібербезпеки та національним індексом кібербезпеки. Загалом за країнами світу спостерігаються тенденції щодо стагнації досліджуваних індексів. 
Економічні науки: збірник наукових праџь Луцького національного технічного університету. - Серія "Регіональна економіка". - Випуск 15 (59). - Редкол.: відп. ред. д.е.н., професор Л.Л. Ковальська. - Луцьк: ІВВ Луичького НТУ, 2018. - 292 с.

Перспективи подальших розробок за даною науковою проблематикою мають бути зосереджені на функціональному та кореляційному аналізі інших індикаторів моніторингу розвитку інформаційно-комунікаційних технологій та засобів масової інформації та побудові за його результатами єдиного інтегрального показника, який буде включати усі аспекти функціонування ринку інформаційно-комунікаційних технологій, та, як наслідок, надавати більш цілісну його характеристику.

1. Про національну безпеку України: Розпорядження Кабінету Міністрів України № 2469-VIII від 21.06.2018 p. URL: http://zakon.rada.gov.ua/laws/show/2469-19 (access date: 04.10.2018).

2. Про рішення Ради національної безпеки і оборони України від 29 грудня 2016 року «Про Доктрину інформаційної безпеки України»: Розпорядження Кабінету Міністрів України № 47/2017 від 25.02.2017p. URL: http://zakon.rada.gov.ua/laws/show/47/2017 (access date: 04.10.2018).

3. Довгий С.О. Передумови становлення інформаційного суспільства в Україні / С. О. Довгий // Азимут-Україна, 2008. - С. 288.

4. Коломієць Г. М. Рейтинги країн за рівнем IT-сфери як індикатори розвитку актуальних форм суспільного багатства / Г. М. Коломі// БізнесІнформ. 2015. Вип. 11. С. 8-15.

5. Sanou B. The role of ICT in advancing growth in least developed countries: trends, challenges and opportunities. Geneva: International Telecommunication Union, 2011. C.184. URL: https://www.itu.int/en/ITUD/LDCs/Documents/Turkey_IV/The_Role_of_ICT_in (access date: 04.10.2018).

6. Farhadi M., Salehi H., Embi M. Contribution of Information and Communication Technology (ICT) in Country's H-Index // Journal of Theoretical and Applied Information Technology. 2013. Вип. 57. №. 1. URL: http://papers.ssrn.com/sol3/papers.cfm?abstract_id=2352672. (access date: 07.10.2018).

7. Бєлай С.В. Дослідження механізмів моніторингу загроз національній безпеці України соціально-економічного характеру / С. В. Бєлай // Університетські наукові записки. 2013. Вип. 4. №. 48. С. 481-488. URL: http://nbuv.gov.ua/UJRN/Unzap_2013_4_60 (access date: 07.10.2018).

8. Гаращук О.В. Соціальна складова національної безпеки та сталого розвитку в умовах глобалізації // Видавничо-поліграфічний центр Тернопільського національного економічного університету «Економічна думка» URL: https://www.google.com/url?sa=t\&rct=j\&q=\&esrc=s\&source= web\&cd=43\&ved=2ahUKEwiArrXosY_eAhWSIYsKHfu4Beg4KBAWMAJ6BAg 
Економічні науки: збірник наукових праџь Луцького національного технічного університету. - Серія "Регіональна економіка". - Випуск 15 (59). - Редкол.: відп. ред. д.е.н., професор Л.Л. Ковальська. - Луцьк: ІВВ Луцького НТУ, 2018. - 292 с.

HEAI\&url=https $\% 3 \mathrm{~A} \% 2 \mathrm{~F} \% 2 \mathrm{Fwww}$.econa.org.ua\%2Findex.php $\% 2$ Fecona $\% 2$ Fartic le $\% 2$ Fdownload $\% 2 F 1266 \% 2 F p d f \& u s g=A O v V a w 3 z E A G P 581100 G o h I u z W 3 w 0$ (access date: 09.10.2018).

9. Кобко Є. В. Моніторинг загроз національній безпеці держави: зарубіжний досвід та українські реалії публічно-правового забезпечення // Є.В. Кобко // Науковий вісник Національної академії внутрішніх справ URL: http://elar.naiau.kiev.ua/bitstream/123456789/4894/1/\%D0\%9A\%D0\%BE\%D 0\%B1\%D0\%BA\%D0\%BE\%20\%D0\%84.\%20\%D0\%92..pdf (access date: 15.10.2018).

10. Глобальний індекс миру 2018. URL: http://bintel.com.ua/uk/article/06_15_gpi/ (access date: 02.10.2018).

11. Про схвалення Концепції розвитку цифрової економіки та суспільства України на 2018-2020 роки та затвердження плану заходів щодо ії реалізації: Розпорядження Кабінету Міністрів України № 67-2018-р від 17.01.2018 p. URL: http://zakon.rada.gov.ua/laws/show/67-2018-\%D1\%80 (access date: 04.10 .2018$)$.

12. GPi - Global Peace Index. URL: http://www.peace.ch/english/GPi.htm (access date: 11.10.2018).

13. Global peace index 2018. URL: http://visionofhumanity.org/app/uploads /2018/06/Global-Peace-Index-2018-2.pdf (access date: 17.10.2018).

14. Global peace index 2016. URL: http://economicsandpeace.org/wpcontent/uploads/2016/06/GPI-2016-Report_2.pdf (access date: 17.10.2018).

15. The production of the WJP Rule of Law Index may be summarized in eleven steps. URL: https://worldjusticeproject.org/our-work/wjp-rule-lawindex/wjp-rule-law-index-2017\%E2\%80\%932018/methodology (access date: 17.10.2018).

16. Rule of law index 2017-2018. URL: https://worldjusticeproject.org/sites/default/files/documents/FINAL_2017-

2018_wjp_rule_of_law_index_HISTORICAL_DATA_FILE.xlsx (access date: 02.10.2018).

17. ITU is the United Nations specialized agency for information and $\begin{array}{llll}\text { communication technologies } & - & \text { ICTs. }\end{array}$ URL: https://www.itu.int/en/about/Pages/overview.aspx (access date: 01.10.2018).

18. Global Cyber security Index (GCI). URL: https://www.itu.int/en/ITUD/Cybersecurity/Pages/GCI.aspx. (access date: 02.10.2018).

19. Global Cybersecurity Index (GCI) 2017. URL: https://www.itu.int/en/ITU-D/Cybersecurity/Documents/Global\%20Cybersecurity\% 20Index\%202017\%20Report\%20version\%202.pdf. (access date: 02.10.2018).

20. National Cyber security Index Methodology. URL: https://ncsi.ega.ee/methodology/ (access date: 09.10.2018).

21. NCSI Cyber Security Index ranking. URL: https://ncsi.ega.ee/ncsiindex/ (access date: 09.10.2018). 